\title{
ANALISA PENGARUH BUDAYA DAN SOSIAL TERHADAP NIAT KONSUMEN DALAM PEMBELIAN RUMAH PADA PERUMAHAN MEWAH DI MAKASSAR
}

\author{
Arnold Phengkarsa ${ }^{1}$, Timoticin Kwanda², Didik Wahjudi ${ }^{3}$
}

\begin{abstract}
ABSTRAK: Penelitian ini dilakukan di kota Makassar, untuk mengetahui faktor-faktor internal yang dipertimbangkan oleh konsumen dalam membeli rumah. Penelitian sebelumnya lebih banyak meneliti tentang faktor eksternal (harga, lokasi, desain, dII) dibanding faktor internal. Faktor-faktor internal yang diteliti terhadap niat konsumen membeli rumah di kawasan perumahan mewah adalah faktor budaya dan sosial. Faktor budaya terbagi atas faktor power distance dan faktor individualism-collectivism. Faktor sosial terbagi atas pengaruh pasangan, pengaruh anak, pengaruh orang tua, dan pengaruh teman. Analisa hasil penelitian dari 204 sampel ini menyebutkan faktor power distance, individualism-collectivism, dan pengaruh anak adalah faktor-faktor yang signifikan terhadap niat pembelian rumah di kawasan perumahan mewah Makassar. Di sisi lainnya pengaruh pasangan hidup, orang tua, dan teman tidak mempunyai korelasi.
\end{abstract}

Kata kunci: power distance,individualism-collectivism, pengaruh pasangan, pengaruh anak, pengaruh orang tua, pengaruh teman, dan niat pembelian.

ABSTRACT: This reseach is accomplished in Makassar to reveal the internal factors considered by consumers in purchasing house. The previous studies were reseached more about external factors (price, location, design, etc) than internal factor. The internal factors were investigated for consumer intention to buy a luxury house, are cuture and social factor. Culture factors are divided into power distance and individualism-collectivism factors. Social factors are divided into spouse's influence, child's influence, parent's influence, and friends' influence. The analysis result of 204 data collected shows the factor of power distance, individualism-collectivism, and child's influence significant to buying intention. except parent's influence does not significant for consumer intention to buy a luxury house.

Keywords: power distance, individualism-collectivism, spouse's influence, child's influence, parent's influence, friends' influence, and purchase intention. .

\section{PENDAHULUAN}

Di Indonesia kebutuhan akan rumah terus meningkat seiring dengan pertumbuhan penduduk. Peningkatan jumlah penduduk dapat berpengaruh terhadap permintaan rumah tinggal. Permintaan akan rumah tinggal kini semakin beragam (Ginanjar, 2009). konsumen untuk membeli rumah, tetapi faktor internal dari konsumen itu sendiri yang dapat mempengaruhi keputusan untuk membeli. Primananda (2010) mengatakan bahwa faktor

\footnotetext{
${ }^{1}$ Mahasiswa Program Studi Magister Teknik Sipil Universitas Kristen Petra, arnold_boa@hotmail.com

2 Dosen Program Studi Magister Teknik Sipil Universitas Kristen Petra, cornelia@petra.ac.id

${ }^{3}$ Dosen Program Studi Magister Teknik Sipil Universitas Kristen Petra, dwahjudi@petra.ac.id
} 
harga, faktor bangunan, faktor lingkungan, dan faktor lokasi mempengaruhi keputusan konsumen membeli rumah; dan Angdika (2008) mengatakan bahwa faktor harga, faktor lokasi, faktor design, dan faktor fasilitas mempengaruhi keputusan konsumen membeli rumah. Faktor-faktor internal dari konsumen dapat terlihat pada perilaku konsumen dalam melakukan keputusan pembelian. Menurut Kotler (2012) keputusan pembelian itu dipengaruhi beberapa faktor, seperti faktor budaya dan sosial. Penelitian yang berkaitan dengan faktor internal konsumen terhadap niat pembelian rumah masih belum banyak diteliti, sehingga dalam penelitian ini ingin mengetahui apakah pengaruh budaya dan sosial berkorelasi terhadap niat konsumen dalam membeli rumah pada perumahan mewah di Makassar.

Tujuan dari penelitian ini adalah untuk mengetahui pengaruh faktor budaya dan sosial terhadap niat konsumen dalam membeli rumah pada perumahan mewah di Makassar. Penelitian ini bermanfaat bagi pengembang untuk membantu mengevaluasi dan sebagai dasar acuan atau pertimbangan dalam menentukan strategi pemasaran yang dapat memenuhi selera dan keinginan konsumen untuk menunjang/memenuhi kebutuhannya masing-masing.

Penelitian ini dilakukan terhadap masyarakat kota Makassar untuk mengetahui pengaruh faktor budaya dan sosial terhadap niat konsumen dalam membeli rumah pada perumahan mewah. Faktor budaya dalam penelitian ini, yaitu power distance dan individualismcollectivism. Sedangkan faktor sosial, yaitu pengaruh pasangan hidup, anak, orang tua, dan teman.

\section{TINJAUAN PUSTAKA}

\subsection{Perumahan}

Menurut Undang-Undang No 1 Tahun 2011 tentang perumahan dan kawasan pemukiman, perumahan adalah kumpulan rumah sebagai bagian dari permukiman, baik perkotaan maupun perdesaan, yang dilengkapi dengan prasarana, sarana, dan utilitas umum sebagai hasil upaya pemenuhan rumah yang layak huni. Perumahan dapat terbagi atas 3 kategori meliputi perumahan sederhana, perumahan menengah, dan perumahan mewah. Rumah sederhana adalah rumah yang luas tanahnya 54-200 $\mathrm{m}^{2}$, rumah menengah adalah rumah yang luas tanahnya 200-600 $\mathrm{m}^{2}$, sedangkan rumah mewah adalah rumah yang luas tanahnya $600-2000 \mathrm{~m}^{2}$.

\subsection{Niat Pembelian}

Keputusan pembelian merupakan kegiatan yang dilakukan secara langsung dalam pengambilan keputusan untuk pembelian terhadap produk atau jasa yang ditawarkan oleh penjual. Keputusan pembelian menurut Kotler (2012) beberapa tahapan, ketika seseorang mengambil keputusan pembelian yaitu pengenalan kebutuhan dan keinginan, pencarian informasi, evaluasi alternative, pembelian, evaluasi pasca pembelian. Penelitian ini berfokus pada pembelian. Konsumen sering kali melakukan pembelian didorong berdasarkan niatnya masing-masing.

\subsection{Perilaku Konsumen}

\subsubsection{Faktor Budaya}

\subsubsection{Power Distance}

Khabiri et al. (2012) mengatakan bahwa power distance yang tinggi mempengaruhi konsumen dalam pembelian barang mewah, dengan memiliki barang mewah dapat menggambarkan status sosial mereka. 


\subsubsection{Individualism-Collectivism}

Menurut Moon et al. (2004) para konsumen dari Negara penganut individualis cenderung membeli produk yang dapat disesuaikan dengan kebutuhan mereka daripada kaum yang menganut kolektivitas, karena kaum individualis ingin mengekspresikan keunikan dari karakter mereka melalui produk yang mereka beli berdasarkan kesesuaian mereka.

\subsubsection{Faktor Sosial}

\subsubsection{Pengaruh Pasangan Hidup}

Menurut Sangkakoon et al. (2014) dalam memutuskan pembelian hunian harus menyadari peran, preferensi dan pengaruh masing-masing anggota keluarga. Secara khusus masingmasing anggota keluarga perlu mengetahui apa saja atribut dari sebuah bangunan yang penting bagi keluarga. Pengaruh suami dibandingkan istri lebih besar, meskipun demikian tetapi akan ada kompromi atau dialog yang menunjukkan pengaruh dari pasangan untuk mengambil keputusan.

\subsubsection{Pengaruh Anak}

Menurut Levy et al. (2004) pengaruh anak-anak dalam pembelian rumah keluarga dianggap sangat penting baik dari sudur pandang langsung dan tidak langsung. Dari sudut pandang tidak langsung, kebutuhan mereka seperti yang dirasakan oleh orang tua mereka membentuk kriteria penting untuk pilihan rumah, misalnya seberapa banyak kamar tidur, lokasi dekat dengan sekolah, lingkungan yang aman, dekat halte bus, dan ukuran halaman. Dari sudut pandang langsung bervariasi berdasarkan dengan usia mereka. Anak-anak yang berusia sekitar 15 tahun, mereka akan mencari ukuran kamar tidur yang layak dan dekat dengan teman-teman mereka.

\subsubsection{Pengaruh Orang Tua}

Menurut Sangkakoon et al. (2004) pengaruh orang tua terhadap anak akan berlanjut, pengertian yang mendalam antar anggota keluarga (orang tua dan anak) akan memungkinkan mereka untuk lebih memahami kondisi masing-masing. Oleh karena itu, orang tua cenderung menyokong kondisi anak-anaknya baik dalam sisi keuangan. Penting bagi orang tua untuk memberikan saran atau masukan kepada anaknya sebagai seorang konsumen, yaitu dengan memberikan pemahaman singkat mengenai alasan-alasan mengapa orang tua merekomendasikan pilihan-pilihan untuk anaknya.

\subsubsection{Pengaruh Teman}

Gallani (2012) mengatakan bahwa konsumen cenderung dipengaruhi oleh konstituen dari kelompok referensi, di antaranya adalah teman dan kerabat. Pengaruh ini akan berdampak dalam mempengaruhi sikap dan perilaku dari konsumen untuk pembelian barang. Pengaruh dari teman cenderung membuat tekanan bagi seseorang untuk mengambil keputusan yang disarankan.

\subsection{Variabel dan Indikator}

Indikator-indikator dari variable independen dan dependen yang dipakai terlampir pada Tabel 1.

Tabel 1. Variabel dan Indikator yang Mempengaruhi Niat Membeli Rumah

\begin{tabular}{|l|l|l|l|}
\hline X1 & Power Distance & X5 & Pengaruh Orang Tua \\
\hline X1.1 & $\begin{array}{l}\text { Adanya urutan ketidaksetaraan } \\
\text { di mana setiap orang memiliki } \\
\text { tempat sesuai haknya. }\end{array}$ & X5.1 & $\begin{array}{l}\text { Orang tua saya berpikir saya perlu } \\
\text { merencanakan untuk membayar cicilan } \\
\text { rumah }\end{array}$ \\
\hline
\end{tabular}




\begin{tabular}{|c|c|c|c|}
\hline$X 1.2$ & $\begin{array}{l}\text { Setiap orang harus memiliki } \\
\text { hak di mata hukum }\end{array}$ & $\times 5.2$ & $\begin{array}{l}\text { Orang tua saya mempengaruhi } \\
\text { keputusan saya membeli rumah }\end{array}$ \\
\hline X1.3 & $\begin{array}{l}\text { Pemegang kekuasaan berhak } \\
\text { untuk memiliki hak-hak } \\
\text { istimewa }\end{array}$ & $x 5.3$ & $\begin{array}{l}\text { Orang tua saya cenderung membantu } \\
\text { pembayaran uang muka untuk membeli } \\
\text { rumah }\end{array}$ \\
\hline X1.4 & $\begin{array}{l}\text { Ketidaksetaraan dalam } \\
\text { masyarakat harus diminimalisir }\end{array}$ & $\times 5.4$ & $\begin{array}{l}\text { Orang tua cenderung membantu } \\
\text { pembayaran cicilan bulanan untuk } \\
\text { membeli rumah }\end{array}$ \\
\hline $\mathbf{X} 2$ & Individualisme & $\times 5.5$ & $\begin{array}{l}\text { Orang tua cenderung memberikan saya } \\
\text { pinjaman untuk membeli rumah }\end{array}$ \\
\hline$X 2.1$ & $\begin{array}{l}\text { Dalam masyarakat, semua } \\
\text { orang seharusnya hanya } \\
\text { mengurusi dirinya sendiri dan } \\
\text { keluarga dekatnya saja }\end{array}$ & $\mathrm{X} 6$ & Pengaruh Teman \\
\hline $\mathrm{X} 2.2$ & $\begin{array}{l}\text { Setiap orang berhak untuk } \\
\text { memiliki kehidupan dan } \\
\text { pendapat pribadi }\end{array}$ & $\mathrm{X} 6.1$ & $\begin{array}{l}\text { Teman saya memberi saran ketika saya } \\
\text { melakukan pembelian rumah }\end{array}$ \\
\hline$X 2.3$ & $\begin{array}{l}\text { Saya dan anggota keluarga } \\
\text { yang lain cenderung } \\
\text { melakukan kesenangan } \\
\text { masing-masing. }\end{array}$ & $\mathrm{X} 6.2$ & $\begin{array}{l}\text { Teman saya mempengaruhi saya untuk } \\
\text { memilih rumah di dekat rumahnya }\end{array}$ \\
\hline$X 2.4$ & $\begin{array}{l}\text { Saya merasa bangga ketika } \\
\text { mencapai apa yang orang lain } \\
\text { tidak dapat capai. }\end{array}$ & $\mathrm{X} 6.3$ & $\begin{array}{l}\text { Teman saya mempengaruhi saya untuk } \\
\text { memilih rumah yang berukuran serupa } \\
\text { dengan rumahnya }\end{array}$ \\
\hline$X 2.5$ & $\begin{array}{l}\text { Sangat penting bagi saya } \\
\text { untuk berkinerja lebih baik dari } \\
\text { orang lain dalam suatu tugas. }\end{array}$ & $\mathrm{X} 6.4$ & $\begin{array}{l}\text { Teman saya mempengaruhi saya ketika } \\
\text { memilih rumah }\end{array}$ \\
\hline$X 2.6$ & $\begin{array}{l}\text { Saya pribadi yang unik dan } \\
\text { berbeda dalam banyak hal } \\
\text { dengan orang lain. }\end{array}$ & $\mathbf{Y}$ & Niat Pembelian \\
\hline $\mathbf{x} 3$ & Pengaruh Suami-Isteri & Y1 & $\begin{array}{l}\text { Saya ingin membeli rumah di kawasan } \\
\text { perumahan mewah }\end{array}$ \\
\hline X3.1 & $\begin{array}{l}\text { Pasangan saya mempengaruhi } \\
\text { saya dalam memilih desain } \\
\text { rumah. }\end{array}$ & Y2 & $\begin{array}{l}\text { Saya cenderung membeli rumah di } \\
\text { kawasan perumahan mewah }\end{array}$ \\
\hline$X 3.2$ & $\begin{array}{l}\text { Pasangan saya mempengaruhi } \\
\text { saya ketika memilih lingkungan } \\
\text { dari rumah. }\end{array}$ & Y3 & $\begin{array}{l}\text { Hal yang logis jika saya membeli rumah } \\
\text { di kawasan perumahan mewah } \\
\text { dibandingkan perumahan sederhana } \\
\text { atau perumahan menengah }\end{array}$ \\
\hline X3.3 & $\begin{array}{l}\text { Pasangan saya mempengaruhi } \\
\text { saya dalam memilih lokasi } \\
\text { rumah. }\end{array}$ & Y4 & $\begin{array}{l}\text { Ada kemungkinan besar saya membeli } \\
\text { rumah di kawasan perumahan mewah }\end{array}$ \\
\hline X3.4 & $\begin{array}{l}\text { Pasangan saya sepakat } \\
\text { dengan saya ketika membuat } \\
\text { keputusan tentang harga } \\
\text { rumah }\end{array}$ & Y5 & $\begin{array}{l}\text { Saya akan mempertimbangkan membeli } \\
\text { rumah di kawasan perumahan mewah }\end{array}$ \\
\hline X3.5 & $\begin{array}{l}\text { Pasangan saya berpikir bahwa } \\
\text { membeli rumah adalah } \\
\text { keputusan yang bijak }\end{array}$ & & \\
\hline $\mathbf{X 4}$ & Pengaruh Anak & & \\
\hline
\end{tabular}




\begin{tabular}{|l|l|} 
X4.1 & $\begin{array}{l}\text { Anak saya menghendaki saya } \\
\text { membeli rumah yang } \\
\text { mempunyai area bermain anak }\end{array}$ \\
\hline X4.2 & $\begin{array}{l}\text { Anak saya menghendaki saya } \\
\text { membeli rumah yang } \\
\text { mempunyai area khusus untuk } \\
\text { anak }\end{array}$ \\
\hline X4.3 & $\begin{array}{l}\text { Anak saya menghendaki saya } \\
\text { membeli rumah yang } \\
\text { mempunyai lingkungan yang } \\
\text { baik untuk anak-anak }\end{array}$ \\
\hline X4.4 & $\begin{array}{l}\text { Anak saya menghendaki saya } \\
\text { membeli rumah yang dekat } \\
\text { dengan rumah temannya }\end{array}$ \\
\hline
\end{tabular}

\section{METODE PENELITIAN}

Penelitian ini dilakukan di Makassar untuk mengetahui niat pembelian konsumen terhadap perumahan mewah berdasarkan faktor budaya dan sosial. Konsumen pada penelitian ini adalah pria dan wanita yang minimal berusia dewasa, mempunyai pekerjaan, dan mempunyai pendapatan. Responden yang dijadikan sampel tidak memiliki kriteria khusus karena dalam penelitian ini hanya mengukur niat pembelian. Sampel yang diambil dalam penelitian ini melalui penyebaran kuisioner di tempat-tempat umum (di pusat perbelanjaan/mall), dan di kawasan perumahan kota Makassar. Skala Likert (skala 1-5) digunakan pada penelitian ini. Teknik penarikan sampel yang digunakan adalah teknik non probability sampling di mana setiap anggota dalam populasi tidak memiliki kesempatan yang sama untuk dijadikan sebagai sampel, sementara tipe non probability sampling yang dipilih adalah convenience sampling, dimana subjek dipilih karena aksesibilitas nyaman dan kedekatan pada peneliti sehingga dapat dijadikan sampel untuk mewakili populasi. Beberapa perumahan yang dijadikan penelitian ini adalah Perumahan Metropolitan Residencen (wilayah pusat kota), Perumahan Tana Toraja (wilayah reklamasi pantai), dan Perumahan Bumi Tamanlanrea Permai (wilayah perbatasan kota).

\section{ANALISA DATA}

\subsection{Deskripsi Data}

Responden berjumlah 204 orang terbagi atas 93 orang laki-laki (45.6\%) dan 111 orang perempuan (54.4\%). Usia responden yang 26-35 tahun sebanyak 87 orang (42.6\%), 36-45 tahun sebanyak 73 orang $(35.8 \%)$, dan 46 tahun ke atas sebanyak 44 orang $(21.6 \%)$. Pekerjaan responden yang sebagai pegawai negeri sebanyak 14 orang $(6.9 \%)$, pegawai swasta sebanyak 95 orang $(46.6 \%)$, professional sebanyak 20 orang $(9.8 \%)$, wirausaha sebanyak 62 orang (30.4\%), dan lainnya sebanyak 13 orang $(6.4 \%)$.

\subsection{Pemeriksaan Data}

\subsubsection{Data Tidak Lengkap}

Pemeriksaan data terhadap adanya data tidak lengkap dari survei ini dilakukan dengan bantuan software SPSS, tidak ditemukan adanya data tidak lengkap.

\subsubsection{Data Pencilan Univariat}

Untuk metode deteksi univariate, Hair et al. (2010) memberikan batas nilai $|z|=3.5$ untuk ukuran sampel lebih dari 80. Bila nilai |z| lebih dari 3.5, perlu dicurigai adanya data pencilan. Dalam penelitian ini, ada lima data yang memiliki nilai $|z|>4$, yaitu 49, 88, 90, 91 dan 186 sebagaimana serta nilai $|z|$ mendekati 4 yaitu 97, 98, 125 dan 190. Selanjutnya, kesembilan data ini tidak diikutkan dalam analisis lebih lanjut. 


\subsection{Reduksi Data}

4.3.1. Power Distance

Variabel power distance terdiri dari empat indikator. Rhyne et al. (2002) mengatakan bahwa indikator X1.2 dan X1.4 nilai dalam skala Likert harus dibalik, istilah ini biasa disebut dengan recode. Pada uji reliablitas dan validitas, baik nilai factor loading dan cronbach's alpha memiliki nilai negative. Hal ini terjadi karena terindikasi bahwa indikator dari power distance ini tidak mengukur hal yang sama, sehingga construct power distance ini tidak dapat dipakai untuk analisa selanjutnya.

\subsubsection{Individualism-Collectivism}

Variabel individualisme terdiri dari enam indikator. Indikator X2.1 yang selalu mengutamakan kepentingan sendiri dan keluarga dekatnya saja, memiliki factor loading rendah (0.396) sehingga dihapus dari model. Reliability dari variabel individualisme juga terlihat baik dengan Cronbach's alpha $=0.704$.

\subsubsection{Pengaruh Pasangan Hidup}

Variabel pengaruh pasangan terdiri dari lima indikator. Kelima indikator memiliki nilai factor loading yang baik dengan loading terendah sebesar 0.557 pada X3.4. Reliability dari variabel pengaruh pasangan juga terlihat baik dengan Cronbach's alpha $=0.877$.

\subsubsection{Pengaruh Anak}

Variabel pengaruh anak terdiri dari empat indikator. Keempat indikator memiliki nilai factor loading yang baik dengan loading terendah sebesar 0.542 pada X4.4. Reliability dari variabel pengaruh anak juga terlihat baik dengan Cronbach's alpha $=0.814$.

\subsubsection{Pengaruh Orang Tua}

Variabel pengaruh orang tua terdiri dari lima indikator. Indikator X5.1 yang mengemukakan bahwa orang tua menyarankan untuk merencanakan pembayaran cicilan rumah memiliki factor loading sangat rendah (0.306) sehingga dihapus dari model. Reliability dari variabel pengaruh orang tua juga terlihat baik dengan Cronbach's alpha $=0.856$.

\subsubsection{Pengaruh Teman}

Variabel pengaruh teman terdiri dari empat indikator. Indikator X6.1 yang mengemukakan penerimaan saran dari teman ketika akan melakukan pembelian rumah memiliki factor loading sangat rendah (0.337) sehingga dihapus dari model. Reliability dari variabel pengaruh teman terlihat baik dengan Cronbach's alpha $=0.819$.

\subsubsection{Niat Pembelian}

Variabel niat pembelian anak terdiri dari lima indikator. Kelima indikator memiliki nilai factor loading yang baik dengan loading terendah sebesar 0.584 pada Y5. Reliability dari variabel pengaruh anak juga terlihat baik dengan Cronbach's alpha $=0.840$.

\subsection{Analisis Hubungan Struktural}

Dalam confirmatory factor analysis yang melibatkan seluruh variabel dalam penelitian diperoleh sebanyak 6 data yang merupakan pencilan multivariate yaitu sampel $84,85,127$, 158,160 , dan 166. Ketujuh sampel tersebut selanjutnya tidak diikutkan dalam analisis lebih lanjut. Dengan demikian tersisa sebanyak 189 sampel dalam penelitian ini yang akan dipakai dalam analisis hubungan struktural (Gambar 1). 


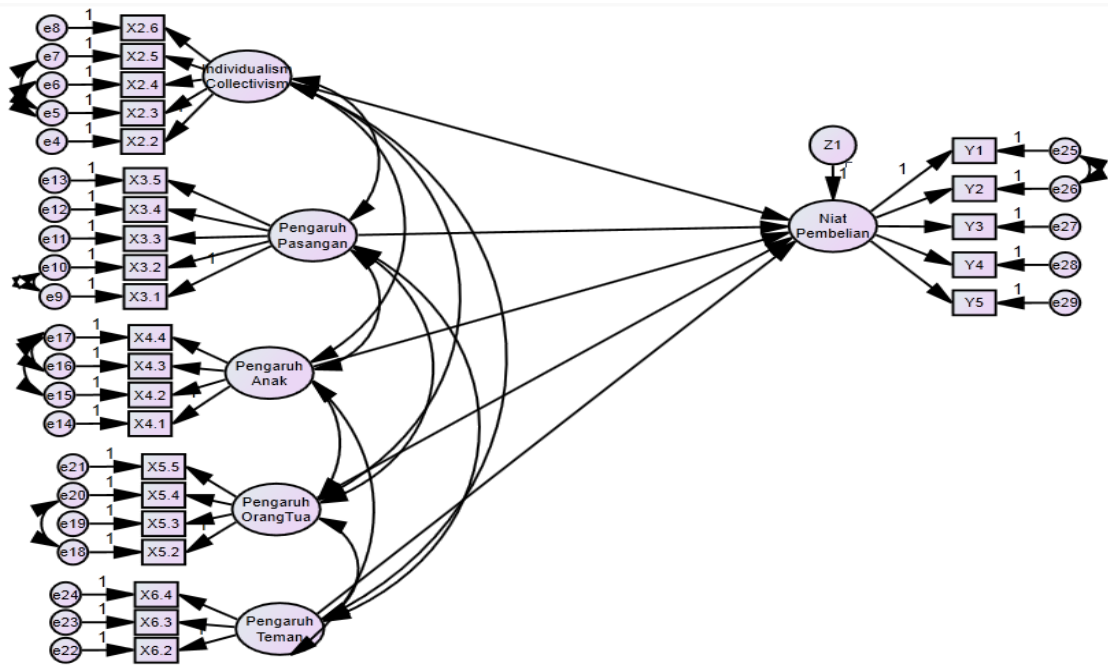

Gambar 1. Model Struktural Faktor Budaya dan Sosial terhadap Niat Pembelian

Hasil analisis menunjukkan bahwa faktor budaya yaitu individualism memiliki pengaruh yang signifikan terhadap niat pembelian rumah oleh konsumen dengan nilai $p$-value $<0.05$. Individualism-collectivism mempunyai $p$-value 0.002 . Sementara itu untuk faktor sosial yaitu pengaruh orang tua disimpulkan juga memiliki tidak berpengaruh signifikan terhadap niat pembelian sedangkan untuk pengaruh pasangan hidup, anak, dan teman dengan nilai $p$ value 0.039 ; 0.045 ; dan 0.041 , semua nilainya $<0.05$, disimpulkan berpengaruh signifikan terhadap niat pembelian rumah oleh konsumen yang ada di kota Makassar. Pengaruh orang tua mempunyai $p$-value 0.16. Model yang menunjukkan good fit sesuai saran dari Hair et al. (2010), yaitu memiliki CMIN/DF < 3,0, CFI > 0,95 dan RMSEA < 0,08. Hasil model secara umum juga cukup mendekati goodness of fit yang cukup baik dimana nilai CMIN/DF $=1.939$ (nilai CMIN/DF < 3), RMSEA $=0.071$ (nilai RMSEA < 0.08), dan CFI $=0.891$ (nilai CFI masih < 0.95). Dengan demikian maka model struktural hubungan pengaruh antara faktor budaya dan faktor sosial terhadap niat pembelian harus dilakukan perbaikan dengan melakukan modifikasi pada model, dengan cara menghilangkan faktor yang tidak berpengaruh terhadap niat pembelian. Faktor yang dihilangkan adalah pengaruh orang tua. Hasil setelah perbaikan diketahui bahwa nilai CMIN/DF = 1.912 (nilai CMIN/DF < 3), RMSEA $=0.07$ (nilai RMSEA < 0,08), dan CFI = 0.91 (nilai CFI sudah mendekati 0.95), oleh karena model sudah mengalami peningkatan dalam kriteria goodness of fit sehingga model struktural yang telah dilakukan perbaikan dengan modifikasi yang akan dipergunakan untuk pembuktian hipotesis penelitian.

\section{KESIMPULAN DAN REKOMENDASI}

\subsection{Kesimpulan}

Hasil studi kuantitatif menyimpulkan bahwa individualism-collectivism, pengaruh pasangan hiduup, pengaruh anak, dan pengaruh teman memiliki korelasi positif terhadap niat konsumen untuk melakukan pembelian rumah mewah, sedangkan pengaruh pasangan pengaruh orang tua tidak memiliki pengaruh terhadap niat konsumen untuk melakukan pembelian rumah mewah di Makassar.

\subsection{Rekomendasi Penelitian Selanjutnya}

Implikasi penelitian dapat memberikan informasi bagi pengembang untuk menyediakan aspek-aspek apa saja yang perlu diperhatikan di perumahan. Informasi ini dapat berfungsi sebagai saran bagi pengembang untuk memenuhi kebutuhan konsumen untuk membeli rumah. Konsumen yang memiliki karakter individualis lebih memilih rumah yang unik sesuai dengan kepribadiannya seperti design rumah, sehingga dapat terlihat berbeda dengan rumah lainnya. Konsumen yang memiliki karakter pro power distance lebih memilih rumah yang dapat menggambarkan tingkat sosial mereka. Pengaruh anak juga akan memiliki dampak dalam niat orang tua untuk membeli rumah. Bagi anak rumah yang memiliki 
lingkungan yang baik buat anak-anak, memiliki area bermain untuk anak-anak, dan memiliki area khusus untuk anak merupakan kebutuhan untuk tempat hunian. Sebagai alternatif penelitian selanjutnya mungkin bisa dimasukkan faktor-faktor budaya lain yang dapat mempengaruhi niat konsumen dalam pembelian di perumahan, seperti uncertainty avoidance, masculinity-femininity, dan long term-short term. Beberapa keterbatasan penelitian ini yaitu, menggunakan convenience sampling, mengalami kendala dalam menerjemahkan literatur luar negeri ke dalam bahasa Indonesia yang baku, dan menggunakan cross sectional.

\section{DAFTAR REFERENSI}

Angdika, S. (2008). Faktor Utama yang Dipertimbangkan Konsumen dalam Membeli Rumah di Puri Mas Regency. Unpublished undergraduate thesis, Universitas Kristen Petra, Surabaya.

Gallani, F. (2012). "Impact of Peer Pressure and Store Atmosphere on Purchase Intention: An Empirical Study on The Youngsters in Pakistan." International Journal of Academic Research in Business and Social Sciences, Vol. 2, No. 7, 323-332.

Ginanjar, Y. (2009). Analisa Korelasi Persepsi Penghuni terhadap Feng Shui Rumah Tinggal di Citraland Berkaitan dengan Aspek Fisik, Lokasi, dan Aksesbilitas. Unpublished undergraduate thesis. Universitas Kristen Petra. Surabaya.

Hair, J.F., Black, W.C., Babin, B.J., and Anderson, R.E. (2010). Multivariate Data Analysis, Seventh Edition. Pearson Prentice Hall.

Indonesia. (2011). Undang-Undang tentang Perumahan dan Pemukiman. Sekretariat Negara, Jakarta.

Khabiri, N., Shomali, S.M., Razeghi, P., and Darvishvand, J.M. (2012). "Influential Factors in Luxury Apparel Purchase Intention among Irianan Customers." Joumal of Basic and Applied Scientific Reseach, Vol.2, No. 12, 670-680.

Kotler, P. (2012). Manajemen Pemasaran. Edisi Keempatbelas. Diterjemahkan oleh Benyamin Molan. Jilid 2, Jakarta.

Levy, D., and Lee, C.K. (2008). "The Influence of Family Member on Housing Purchase Desicions." Joumal of Property Investment \& Finance, Vol. 22, No. 4, 320-338.

Moon, J., Chadee, D., and Tikoo, S. (2004). Culture, Product Type, and Price Influences on Consumer Purchase Intention to Buy Personalized Products Online. Hanyang University, Anyang.

Primananda, A. (2010). Faktor-Faktor yang Mempengaruhi Konsumen dalam Membeli Rumah. Universitas Diponegoro, Semarang.

Sangkakoon, P., Ngarmyarn, A., and Panichpathom, S. (2014). The Influence of Groups References in Home Purchase Intention in Thailand. Thammasat University, Bangkok. 